\title{
EDITORIAL
}

\section{The International Court of Justice in the Leiden Journal: A Retrospective}

\author{
JASON MORGAN-FOSTER, GIULIA PINZAUTI AND PHILIPPA WEBB*
}

Last year the International Court of Justice (ICJ) marked its seventieth anniversary, and in the most recent issue of the Leiden Journal of International Law, Hugh Thirlway recognized this milestone with a look back through some key developments at the Court, focusing on the last few years. Here, we would like to undertake a retrospective of another sort, paying tribute to the ongoing connection between the Court and the Journal by taking a brief tour through the Journal's coverage of the Court over the years. It is hoped that this retrospective will not only bring back some fond memories but also - by viewing this material as a whole, and pointing out certain gaps in the Journal's coverage of the Court's work - stimulate future analyses.

The Court's seventieth anniversary (which immediately precedes the Journal's thirtieth anniversary this year) seems a fitting moment for this exercise. Indeed, at a time when the Court's docket is busy with I 4 cases, ${ }^{\mathrm{I}}$ we (as members of the editorial board's ICJ section) sometimes struggle to find pieces on the Court that are suitable for publication in the Journal. The issue is not so much the quality of the submissions we receive, but their quantity. In contrast, we see that the case law of other courts and tribunals attracts more attention by prospective Journal authors. We would like to identify the reasons behind the decline in interest in writing about the Court for the Journal in recent years. With this consideration in mind, we turn to analyze the scholarly contributions on the Court published in the Journal over the past 30 years. ${ }^{2}$

Looking back at this scholarship, we note that interest in the Court has shifted back and forth from issues raised by pending cases to more general questions such as procedural issues and impact, with the former type of contributions significantly outnumbering the latter.

Of the case-related pieces, it is unsurprising that it is the Court's pronouncements now considered as 'landmark' that have inspired the most commentaries. These

Members of the Editorial Board [j.morgan@icj-cij.org], [g.pinzauti@law.leidenuniv.nl], [philippa.webb@ kcl.ac.uk]. Views are the authors' own.

As of March 2017.

Given the number of contributions published in the Journal, the following analysis does not purport to be exhaustive. 


\section{include the two Advisory Opinions on nuclearweapons, ${ }^{3}$ thejudgmentsin Arrest War- rant ${ }^{4}$ and Avena, ${ }^{5}$ the Wall ${ }^{6}$ and the Kosovo Advisory Opinions, ${ }^{7}$ the Genocide cases, ${ }^{8}$}

3 In vol. 8, Martin Lailach discussed the process within the General Assembly culminating in the request to the Court for an advisory opinion on the legality of the threat or use of nuclear weapons, providing an interesting historical account of the negotiations within the Assembly which preceded this important opinion by the Court. In vol. Io, Chittharanjan F. Amerasinghe, renowned for his expertise in institutional law, provided a thoughtful commentary on the 'other' Nuclear Weapons advisory opinion of I996, that was rendered in response to the request by the World Health Organization (WHO), in which the Court concluded that it had no jurisdiction to consider the question because the request was outside the scope of the WHO's activities as defined by its Constitution.

4 In vol. I6, two articles appeared in the Journal dedicated to that decision. Alain Winants, an Advocate General at the Brussels Court of Appeal, provided an overview of the 1993 Belgian law on universal jurisdiction which was at issue in the case and argued that the Court was overly conservative in its conclusion that high-ranking officials enjoy immunity from civil and criminal jurisdiction in other states, a conclusion which he contended would lead to de facto impunity for those officials. Jan Wouters was also highly critical of the judgment, focusing in particular on the methodology of the Court in establishing the existence of a customary international law norm on immunity of high officials before the national courts of other states, as well as the Court's refusal to pronounce on the issue of universal jurisdiction.

5 The Avena case spawned several articles, beginning in vol. I7 with a piece by Robert D. Sloane concerning Avena's place in the Court's provisional measures jurisprudence, and continuing in vol. I 8 with contributions from Alexander Orakhelashvili (considering judicial remedies in Avena), Christopher J. Le Mon (examining early decisions of US Courts following Avena) and Annemarieke Künzli (focusing on the Court's consideration of diplomatic protection and the local remedies rule). Interest in the case and its aftermath continued in vol. I8, with a review essay by Dirk Pulkowski analyzing different compliance theories (developed in books by Benvenisti and Hirsch, Burgstaller, and Schulte) through the lens of the Avena case. In vol. 22, John King Gamble and Christine M. Giuliano wrote on the US Supreme Court's decision in Medellín v. Texas, concluding that it was not directly enforceable federal law in the United States.

6 Paul J.I.M. De Waart and Jean-François Gareau in vol. I8, and Aeyal M. Gross and Iris Canor in vol. I9 commented on the Opinion. Whereas De Waart praised the Opinion, regretting only that the General Assembly had not asked the Court sooner, Canor was rather critical of it, in particular the Court's conclusion that Israel could not invoke a right of self-defence against terrorism to justify the building of the wall. Gareau's piece appraised the impact of the Opinion on the development of self-determination as a legal principle, and Gross compared the Court's Opinion with two decisions by the Israeli Supreme Court on the legality of particular sections of the wall.

7 First, in vol. 22, Zoran Oklopcic wrote on the Kosovo declaration of independence, shortly after the General Assembly had made its request. In vol. 24, the Journal published the papers of a symposium on the Kosovo Advisory Opinion held at the University of Cambridge, including contributions from Theodore Christakis (examining how the Court dealt with existing general international law governing secession), Olivier Corten (considering the Court's premise that the scope of the principle of territorial integrity is confined to relations between states), Hurst Hannum (emphasizing that a definitive resolution of Kosovo's status could only occur through agreement between Pristina and Belgrade), Dov Jacobs and Yannick Radi (focussing on the Court's judicial function and its discretion to refuse to answer the question or to reformulate it), Marcelo G. Kohen and Katherine Del Mar (criticizing the Court's conclusion that the declaration of independence did not violate Security Council Resolution I244), Marc Weller (coming to the opposite conclusion that the declaration is entirely consistent with Resolution I244), Anne Peters (examining aspects of the Court's reasoning, such as its treatment of the Lotus principle), Jure Vidmar (on how the Court confined the scope of its opinion), and Ralph Wilde (on the finding that sub-state groups are free to unilaterally terminate a Security Council-imposed process).

8 In vol. 20, Anna Riddell's voluminous contribution on procedural and evidentiary issues focused on the conduct of the proceedings in the Bosnian Genocide case. Volume 2I was almost entirely dedicated to that case, with articles by Chittharanjan F. Amerasinghe (a general analysis of the case), Vojin Dimitrijević and Marko Milanović (exploring the larger political context of the case), Richard Goldstone and Rebecca Hamilton (discussing the interplay between the Court and the International Criminal Tribunal for the former Yugoslavia), Jörn Griebel and Milan Plücken (focusing on the rules of attribution as applied in the case), and Nikolas Rajković (considering the relationship between law and politics in the judgment). In vol. 22 Marko Milanović commented on Griebel and Plücken's article of the prior year, further expounding on the attribution test used by the Court.

In vol. 28, the Journal published a mini-symposium of six articles on the Croatian Genocide case. Payam Akhavan wrote on the Court's narrow reading of jurisdiction ratione temporis under Article IX of the Genocide Convention; Andrea Gattini and Giulio Cortesi on the Court's handling of evidence; Caroline Fournet on the Court's treatment of actus reus of genocide; Paul Behrens on the Court's treatment of genocidal intent; Martin 
Diallo, ${ }^{9}$ and the Jurisdictional Immunities Judgment. ${ }^{\text {Io }}$ Similarly, the Journal has also published retrospectives on some of the Court's leading past cases, such as those related to South-West Africa, ${ }^{\text {II }}$ Barcelona Traction, ${ }^{\text {I2 }}$ and Nicaragua. ${ }^{\text {I3 }}$

Scholars are keen to write on cases that concern the use of force, immunities, diplomatic protection and consular relations, military occupation, and the right to self-determination. But there is more limited interest in writing about the Court's jurisprudence on territorial and maritime disputes, ${ }^{\mathrm{I}}{ }^{4}$ even though such cases have been a constant on the docket and continue to represent a significant share of the Court's caseload. Boundary cases are also undoubtedly very significant for the states concerned. Perhaps scholars are more interested in the Court's shaping of controversial legal issues (e.g., whether there is a jus cogens exception to state immunity) than the fact-intensive exercise of delimitation? In overlooking the Court's case law on territorial and maritime disputes, scholars neglect to analyze the cases that probably have the greatest impact on the communities concerned, in addition to influencing the International Tribunal for the Law of the Sea and ad hoc arbitral tribunals. Analyzing these cases would provide a window onto the Court's dispute

Steinfeld on the Court's treatment of ethnic cleansing; and Giulia Pecorella on the Court's strict threshold requirements that rape and sexual violence contribute to the physical destruction of the group to satisfy the required actus reus.

9 AnnemariekeVermeer-Künzli published twice on the Diallo case, in 2007 (vol. 20), where she analyzed the application of the International Law Commission's Draft Articles on Diplomatic Protection in the case, and in 20 I I (vol. 24).

ro Andrea Gattini first commented on the case in vol. 24 (while the dispute between Germany and Italy was pending). In vol. 25, the Journal also published articles on the judgment by François Boudreault and Stefan Talmon. Boudreault analyzed conflicts of norms, offering an alternative to the substantive/procedural distinction used by the Court, ultimately reaching the same conclusion that there was no conflict of norms between jus cogens and state immunity. Talmon defended the distinction drawn by the Court between substantive and procedural rules, arguing that substantive rules of a jus cogens character generally leave procedural rules unaffected and, in particular, do not automatically override such rules. In vol. 26, Alexander Orakhelashvili wrote a response piece to Stefan Talmon's article. Orakhelashvili was highly critical of the decision, arguing that the distinction between substantive and procedural rules was artificial, not reflective of the functions international law actually accords to its various rules and was rather a product of political and ideological preference to keep particular classes of plaintiffs out of certain jurisdictions. In the same volume, the Journal published a piece on the case by Matteo Sarzo. See also, in relation to immunities, Gionata P. Buzzini on Djibouti v. France in vol. 22.

II In vol. I2, Michla Pomerance provided a fascinating retrospective on the Court's four advisory opinions and two judgments that make up its overall treatment of South West Africa. The piece contains many insights not only about the cases related to South West Africa, but also about diverse issues treated therein, such as the respective roles of advisory opinions and contentious cases, and the formation of customary international law.

I2 In vol. 23, Christian Tams and Antonios Tzanakopoulos looked back at the Barcelona Traction case 40 years on.

I3 Volume 25 contained the papers of a fruitful symposium on the Nicaragua case entitled 'Nicaragua: 25 Years Later', held on 27 June 20 I I, exactly 25 years to the day after the Nicaragua Judgment was delivered. The stature of the contributors reflected the case's importance, with contributions from Abdulqawi Yusuf, considering the notion of 'armed attack' in the Nicaragua Judgment and its influence on subsequent case law; James Crawford, reappraising the Court's approach to jurisdiction and applicable law in the Nicaragua case; Marcelo Kohen, writing on the principle of non-intervention 25 years after the judgment; Paul S. Reichler, covering the impact of the Nicaragua case on matters of evidence and fact-finding; and by Alain Pellet and Lori Fisler Damrosch, each offering an analysis of the impact of the case on the Court and its role.

I4 In vol. I3, John G. Merrills offered an invaluable survey of the land boundary cases the Court had decided to that point, including eight contentious cases and one advisory opinion, covering not only the substantive aspects of those cases but also jurisdictional issues and questions of implementation. It took more than a decade before another scholar, Yoshifumi Tanaka, published a piece on the case concerning Territorial and Maritime Dispute (Nicaragua v. Colombia) in vol. 26. 
settlement role, its fact-finding function, and its treatment of (or detachment from) the political, economic, cultural and social factors that swirl around the question of where a boundary line is drawn.

Another significant trend in the scholarship on the Court has been its reflection on incidental proceedings, most notably on the indication of provisional measures by the Court, ${ }^{15}$ but also on preliminary objections and counter-claims. ${ }^{16}$ Scholars have also commented on the increasing role of scientific fact-finding in cases before the Court. ${ }^{17}$ In hindsight, scholars have focused on new developments in the Court's practices, for example following changes in the rules or where the Court was setting a new precedent. ${ }^{18}$ In contrast, other evidentiary and procedural matters, including intervention, have received less attention by the Journal's authors ${ }^{19}$ (in the case of intervention, this could be explained by the fact that it has been used more sparingly than other incidental proceedings).

It seems logical that when the Court was shaping a controversial or novel legal issue, or setting a new precedent with its decisions, whether on substantive or procedural matters, comments from legal scholars flourished, both critical and complimentary. We can only speculate as to why some of the Court's more recent cases have not attracted as much commentary. Have legal scholars turned their attention to other, newer courts focused on human rights, trade, international criminal law or compliance with regional conventions?

To some extent, it is the attention that scholars give to a particular decision that makes it a 'landmark' from a doctrinal point of view, which may not necessarily be proportionate with its actual impact on the communities concerned. It is true that in recent years the Court's docket has been dominated by jurisdictional issues, and by disputes over land and maritime boundary delimitations. We have already seen that scholars have limited appetite for such cases. ${ }^{20}$ Moreover, there is a perception that the Court's posture, as reflected in its recent decisions on jurisdiction, has

I5 In vol. 2I, Paolo Palchetti's argued that by attaching relevance to the element of aggravation, the Court had been able to indicate provisional measures that may not have been strictly needed if only irreparable harm had been examined. Two years later (vol. 23), Gentian Zyberi took a further look at the indication of provisional measures by the Court, noting the difficulty in using such measures to deal with major political controversies resulting in inter-state armed conflict.

I6 In vol. I2, Hugh Thirlway offered a detailed overview of the state of the law governing counter-claims before the Court, including an analysis of the Court's orders on counter-claims in the cases concerning Application of the Convention on the Prevention and Punishment of the Crime of Genocide (Bosnia and Herzegovina v. Serbia and Montenegro) and Oil Platforms (Islamic Republic of Iran v. United States of America), but also a historical account of the law on counter-claims back through to the Permanent Court. In vol. I4, Shabtai Rosenne discussed the 200I revisions to Arts. 79 and 80 of the Rules of Court, dealing with preliminary objections and counter-claims, respectively.

17 In vol. I I, Frances Meadows provided a useful account of the purpose of the Court's historic site visit in the Gabčikovo-Nagymaros case, viewed in the context of the Court's specific judicial function under its Statute and rules. Two decades later, this first site visit remained the only such visit by the Court as a whole under Art. 66 of the Rules of Court, although in a pending case the Court arranged for an expert opinion under Art. 67 of its Rules and called for the experts appointed to visit the site; Maritime Delimitation in the Caribbean Sea and the Pacific Ocean (Costa Rica v. Nicaragua), Order of 3I May 20I6, para. Io(2).

I8 'Precedent' is used in a broad sense since the Court technically has no doctrine of stare decisis (Art. 59 of the Statute).

I9 In addition to Riddell's contribution (supra note 8), in vol. 25 Beatrice I. Bonafé wrote a piece on the 'interest of a legal nature' test in interventions.

20 In the past, there have been few contributions on states' acceptance of the Court's jurisdiction and the 'indispensable third party' principle articulated by the Court in East Timor. The first appearance of the 
been leaning towards formalism over flexibility. This marks a significant departure from the Court's longstanding tradition of flexibility and pragmatism in dealing with evidentiary and jurisdictional questions, such as the existence of a dispute between the parties. ${ }^{2 \mathrm{I}}$ These factors, coupled with the proliferation of many other international courts and tribunals, may have contributed to a certain decline in scholarly attention towards the Court.

The Journal has, for the past 30 years, been witness to the most important developments at the Court, from the viewpoint of both substantive and procedural law. Arguably, however, scholars have not reflected on the full range of the Court's functions. For instance, few commentators have considered the role of the Court in contemporary international law, ${ }^{22}$ or the changing attitude of states towards judicial and arbitral dispute settlement. ${ }^{23}$ The Journal has also seen comparatively few articles on 'big picture' issues, such as the Court's contribution to human rights law, international humanitarian law, ${ }^{24}$ the protection of cultural rights, ${ }^{25}$ and treaty

ICJ within the pages of the Journal considered the very beginning of the Court's treatment of disputes: acceptance of the Court's jurisdiction by states. In a special issue in vol. 3 dedicated to The United Nations Decade of International Law, Juan J. Quintana lamented the fact that, in the I989 Declaration by the NonAligned Movement calling upon the United Nations General Assembly to declare a Decade of International Law, a clause was deleted which provided for goodwill missions to all Non-Aligned Movement states which had not yet accepted the compulsory jurisdiction of the Court, in order to encourage those states to do so. In vol. I4, Stanimir A. Alexandrov offered an excellent overview of state practice in accepting the compulsory jurisdiction of the Court with conditions. He noted that while over 60 states had accepted the Court's compulsory jurisdiction (it is now 70), all such declarations made during the decade preceding his analysis contained various conditions. Alexandrov emphasized the effect of the principle of reciprocity on conditions in optional clause declarations: states that 'over-protect' themselves not only restrict their own rights to initiate international adjudication against other states but also, when applied reciprocally to all other states, substantially weaken the entire compulsory jurisdiction of the Court. In vol. 9, Iain Scobbie and Catriona Drew provided a critique of the Court's judgment in the East Timor case, the former having served as Counsel to the Government of Portugal.

2I See, e.g., D. West, 'Formalism Versus Realism: The International Court of Justice and the Critical Date for Assessing Jurisdiction', (20I6) 5 UCL Journal of Law and Jurisprudence 3I. See generally D. Bodansky, 'Legal Realism and its Discontents', (20I5) 28 LJIL 267; P. Okowa, 'The International Court of Justice and the Georgia/Russia Dispute', (20II) I I Human Rights Law Review 739, at 749-50; N. Krisch, 'Capitulation in The Hague: The Marshall Islands Cases', EJIL:Talk!, ıo October 20I6, available at www.ejiltalk.org/ capitulation-in-the-hague-the-marshall-islands-cases/; E. Stoppioni, "The ICJ Decisions in the Marshall Islands Cases or the Unintended Consequences of "Awareness"', SIDIBlog, 24 November 20I6, available at www.sidiblog.org/20 I6/I I/24/the-icj-decisions-in-the-marshall-islands-cases-or-the-unintendedconsequences-of-awareness/.

22 In vol. I5, Martti Koskenniemi and Päivi Leino brought the then-popular fragmentation debate to the Court, observing that while successive ICJ Presidents had expressed concern about the proliferation of international tribunals and the substantive fragmentation of international law, their anxiety should be seen less as a concern for abstract 'coherence' than a worry about the demise of traditional principles of diplomatic law and the Court's privileged role as their foremost representative. In vol. 26, Armin von Bogdandy and Ingo Venzke reflected on the role of international courts, mostly taking the Court as the central point of reference.

23 In vol. 6, Edward McWhinney considered the differences between the Court and arbitral tribunals, questioning why the Permanent Court of Arbitration(PCA) had seen only two cases between I93 I and the time he was writing in I993, and had essentially devolved into a complex mechanism for listing nominees to the ICJ. It is worth noting that the PCA had a case load of 138 cases in 20I5, including eight inter-state arbitrations, while the ICJ did not receive a new application that entire year. See 2015 Annual Report of the Permanent Court of Arbitration, p. 8, available at www.pca-cpa.org. In vol. 28, the Journal published a piece by Vice-President Yusuf on the evolving attitude of African states towards judicial and arbitral settlement of disputes.

24 In vol. 20, Rosalyn Higgins wrote on 'Human Rights and the International Court of Justice' and Fabián O. Raimondo analyzed 'The International Court of Justice as a Guardian of the Unity of Humanitarian Law'.

25 In vol. 27, Eleni Polymenopoulou offered an interesting assessment of cultural rights in the case law of the Court, including in the Navigational Rights (2010), Frontier Dispute (2013) and Preah Vihear (2013) cases. She 
interpretation. ${ }^{26}$ Remedies ${ }^{27}$ and the enforcement of the Court's judgments ${ }^{28}$ have been the subject of thought-provoking contributions, but have not been fully explored yet. Likewise, there is, no doubt, more to say on the role that individual opinions play at the Court. ${ }^{29}$

Moreover, in our view, scholars have not picked up on some recent developments in the Court's case law and practice. The spate of preliminary objections proceedings in recent years, for example, invites analysis of the Court's developing jurisprudence on jurisdiction and admissibility. It would also be interesting to consider the increased litigation before the Court dealing with the obligation to negotiate, in particular the case brought by Bolivia against Chile concerning an obligation to negotiate access to the Pacific Ocean and, albeit never reaching the merits, the case brought by the Marshall Islands against multiple respondents concerning the obligation to pursue in good faith negotiations on nuclear disarmament. The Court's constantly growing jurisprudence on maritime delimitation is also ripe for commentary. The 2016 Somalia v. Kenya Judgment raises questions about how the Court interacts with the UNCLOS framework for dispute settlement.

Another interesting subject which could find its way into the pages of the Journal is the decision of the Court to resume the proceedings in the Congo v. Uganda case on the question of reparations, ten years after its merits judgment. This invites commentary on the applicable standards for assessing compensation in the case of large-scale violations of human rights law, humanitarian law and the law on diplomatic relations. The six new cases initiated since June 2016 could also provide excellent opportunities for commentary.

In sum, there are rich areas for further research and writing. Scholarship on the Court is important not only for the broader legal community, but also for its potential impact on the Court itself. Relevant scholarship is brought to the attention of the Judges and the Court's legal staff. The Journal has become a place to refer to for

noted that the Court had considered questions of cultural rights as beyond the applicable jurisdictional basis in the Genocide (2007) and Racial Discrimination (201 I) cases.

26 For example, Martin Dawidowicz wrote in vol. 24 on the effect of passage of time on the interpretation of treaties (focusing on Dispute regarding Navigational and Related Rights (Costa Rica v. Nicaragua)). In vol. 29, Peter Quayle examined the Court's interpretation of constituent instruments of international organizations, showing ways in which it can differ from the general rules of treaty interpretation provided under the Vienna Convention on the Law of Treaties and why this may allow for a more efficient and effective approach to the interpretation of this unique type of treaty.

27 Volume 29 featured a piece by Juliette McIntyre on the role of the declaratory judgment in the jurisprudence of the Court.

28 In vol. I5, Mutlaq Al-Qahtani offered an interesting new perspective on possible ways that the Court could become more involved in the enforcement of its judicial decisions, such as the powers under Art. 78 of its Rules to request information from the parties about implementation of provisional measures and under Art. $6 \mathrm{I}(3)$ of its Statute in revision proceedings to require previous compliance with the terms of the judgment before admitting proceedings in revision.

29 In vol. I7, Jörg Kammerhofer questioned the high number of separate and dissenting opinions (II) in Oil Platforms, a case which had only three negative votes cast in the dispositif. He argued that judges were doing a disservice to the authority of the Court's judgment by expounding so many individual opinions. It is worth noting that in Application of the Convention on the Prevention and Punishment of the Crime of Genocide (Croatia $v$. Serbia), there were 12 opinions and declarations, despite the fact that the operative paragraphs were adopted either unanimously or by rather large majorities ( 5 votes to two and I I votes to six). In Whaling in the Antarctic (Australia v. Japan: New Zealand intervening), the smallest majority in an operative paragraph was I 2 votes to four, and yet I I opinions and declarations were attached. 
detailed and thought-provoking analysis of developments in the Court's case law and practices, or theories on future directions.

A final remark on the scholarship about the Court published in the Journal concerns its authorship. We cannot but note that the Journal has regularly featured within its pages some of the most renowned scholars on the International Court of Justice, including current and past members of the Court and members of the International Bar. We are honoured to publish their insights on the Court. The Journal has also published contributions by new voices, but relatively few young scholars have sought to publish their research on the Court in the Journal in recent years. There must be many young lawyers interested in the work of the Court, judging from the hundreds of applications that the Registry receives every other year for the positions of law clerk to Judges of the Court. Perhaps law blogs have become a preferred forum for quick commentary by young scholars. Perhaps commenting on the work of the World Court may appear as a daunting task. But we wish to emphasize that the Journal remains committed to giving a voice to individuals who are not regular commentators on the Court.

As it begins its fourth decade of coverage of the International Court of Justice, it is hoped that the Leiden Journal of International Law can remain a place where commentators of all sorts - from new voices to longstanding scholars of the Courtmay bear witness to the continued developments at the principal judicial organ of the United Nations. 